\title{
"Customer value and customer brand engagement: Their effects on brand loyalty in automobile business"
}

\begin{tabular}{|c|c|}
\hline AUTHORS & $\begin{array}{l}\text { Sid Terason (iD) } \\
\text { Shixin Zhao (i) } \\
\text { Pirayut Pattanayanon (D) }\end{array}$ \\
\hline ARTICLE INFO & $\begin{array}{l}\text { Sid Terason, Shixin Zhao and Pirayut Pattanayanon (2021). Customer value and } \\
\text { customer brand engagement: Their effects on brand loyalty in automobile } \\
\text { business. Innovative Marketing , 17(2), 90-101. doi:10.21511/im.17(2).2021.09 }\end{array}$ \\
\hline DOI & http://dx.doi.org/10.21511/im.17(2).2021.09 \\
\hline RELEASED ON & Monday, 24 May 2021 \\
\hline RECEIVED ON & Tuesday, 06 April 2021 \\
\hline ACCEPTED ON & Monday, 17 May 2021 \\
\hline LICENSE & $\begin{array}{l}(c) E_{\text {EY }} \\
\text { This work is licensed under a Creative Commons Attribution } 4.0 \text { International } \\
\text { License }\end{array}$ \\
\hline JOURNAL & "Innovative Marketing " \\
\hline ISSN PRINT & $1814-2427$ \\
\hline ISSN ONLINE & $1816-6326$ \\
\hline PUBLISHER & LLC "Consulting Publishing Company "Business Perspectives" \\
\hline FOUNDER & LLC "Consulting Publishing Company "Business Perspectives" \\
\hline
\end{tabular}

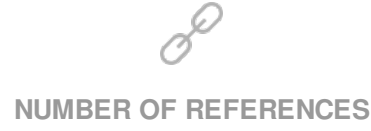

50

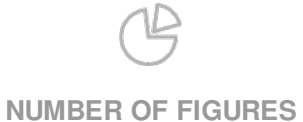

2
E=-

NUMBER OF TABLES

2

(C) The author(s) 2021. This publication is an open access article. 


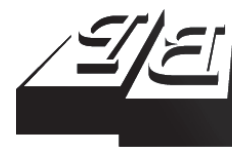

\section{BUSINESS PERSPECTIVES}

LLC "CPC "Business Perspectives" Hryhorii Skovoroda lane, 10, Sumy, 40022, Ukraine www.businessperspectives.org
Received on: $6^{\text {th }}$ of April, 2021 Accepted on: $17^{\text {th }}$ of May, 2021 Published on: $24^{\text {th }}$ of May, 2021

(๑) Sid Terason, Shixin Zhao, Pirayut Pattanayanon, 2021.

Sid Terason, Associate Professor, Faculty of Sport Sciences, Kasetsart University, Thailand. (Corresponding author)

Shixin Zhao, Lecturer, College of Innovation and Management, Suan Sunandha Rajabhat University, Thailand.

Pirayut Pattanayanon, Lecturer, Faculty of Business Administration, Thonburi University, Thailand.

CUSTOMER VALUE AND CUSTOMER BRAND ENGAGEMENT: THEIR EFFECTS ON BRAND LOYALTY IN AUTOMOBILE BUSINESS

\begin{abstract}
The study investigates the extent to which customer value affected brand loyalty among mid-sized automobile customers in Thailand. It's focused on assessing whether customer brand engagement acted as an intervening variable in the relationship between customer value and brand loyalty. A questionnaire was distributed to a random sample of 380 current users of medium-sized passenger automobiles in Thailand; these participants were drawn from the list of automobile customers using a multistage sampling technique. The dealership customers were asked to complete an electronic survey using their cell phones. Structural equation modeling was applied to prove the theoretical model. All the model fit indices revealed that the model was reasonably consistent with the data. Results validated customer brand engagement composed of three dimensions using confirmatory factor analysis and its role as a mediator. The findings also provided novel insight into the interplay of the relevant variables and could be used as a guideline for managing automobile customers and promoting automobile marketing in the country.
\end{abstract}

Keywords

JEL Classification

\section{INTRODUCTION}

Marketing researchers have long been intrigued by the effect customers can have on product success. There are contributing factors that drive the commercial success of a product - customer value remains one of them and has been studied extensively in the past several decades (Chang \& Weng, 2012; Lee et al., 2018; Woodruff, 1997). Nevertheless, while these studies have described and developed the construct of customer value, there is little empirical research on the automobile industry.

Thailand's automobile business has been one of the most vibrant sectors that has driven the growth of the country's economy in recent decades (Maikaew, 2019), considering Thailand is the biggest hub of automobile production for both domestic and foreign markets. Maikaew (2019) affirmed that Thailand's automobile industry employed about 850,000 people and contributed to $10 \%$ of the country's gross domestic product. The domestic sales hit a record of 1.43 million units sold with a growth rate of $12 \%$ a year. Nonetheless, the situation has been deteriorated since then. The automobile industry has experienced brand switching among current customers in recent years. The dealerships were uncertain about how to retain their customer base and generate repeat purchase in an appropriate timeframe in order to cover daily operating expenses. Besides 
the shrinking export volume, the domestic demand has reduced to 0.8 million units sold with the growth rate of $2 \%-3 \%$ since 2015 (Maikaew, 2019).

The traditional marketing approach is no longer effective in sustaining customer relationship in the automobile business. During the past decades, automobile manufacturers believed that product differentiation was the key to business success (Albert et al., 2008). Consequently, they attempted to create the best of product with distinctive features. Unfortunately, the consumers appreciated quality in products but failed to see any differences among brands (Yoo \& Donthu, 2001). Only those who are inventive and original in contriving new ideas can survive in the market. Hence, all sectors in the market must rethink about the way they conduct marketing and probably must shift from brand satisfaction to customer brand engagement (CBE) to be in line with value-orientation trend. In other words, marketers must change their business perspectives from customer acquisition to customer retention.

To keep the best marketing efficiency in retaining customers, it may or may not be necessary to spend all available marketing budget on all existing customer values. The authors strongly believed that some customer values are more prominent than others because current customers themselves also prefer some values over others.

\section{LITERATURE REVIEW}

Customer value is considered an important strategic part used by companies to attract and retain customers (Rus, 2016). The customer value refers to the result of customer perception of product attributes or functionalities and is derived from reaching the customers' expectations when they use the product (Woodruff, 1997). To produce expected business outcomes, a company must be aware of the way various customer values affect consumers' brand choice.

Specifically, it was clear from numerous studies that customer value was one of the antecedent factors of CBE. Hollebeek and Chen (2014) proposed that customer value had an impact on CBE. Verma et al. (2016) indicated that customer value was positively related to CBE with social network rampage. Hapsari and Dean (2016) demonstrated that CBE was influenced by perceived customer value. Furthermore, Vargo and Lusch (2014) maintained that companies that created positive brand experiences for their engaged customers tended to improve perceived value.

In marketing, functional customer value is widely examined, whereas experiential customer value has been regarded as a factor affecting a customer's brand choice (Lee et al., 2018). Functional value was characterized as task-related, reasonable and related to information gathering (Babin et al., 1994). Experiential value refers to a subjective, personal, interactive feeling derived from fun and playfulness instead of from work completion. It was asserted that functional customer value did not drive brand equity toward purchase of a high-involvement product (Delgado-Ballester \& Munuera-Alemán, 2005).

Furthermore, Rus (2016) tested an interrelationship of perceived value, satisfaction, and loyalty among automobile owners. It was affirmed that functional customer value influenced satisfaction, but did not brand loyalty, whereas experiential value had an impact on both satisfaction and brand loyalty. Since functional and experiential customer value is indicated to influence satisfaction, Fernandes and Moreira (2019) proved that functional customer value drove satisfaction, while satisfaction and $\mathrm{CBE}$ were significantly related.

Social customer value is found to be more important, since nowadays consumers call upon businesses to be socially responsible. More companies have been adopting sustainable strategies and implementing more socially responsible practices. Patrick (2002) defined social value as the product's benefit/value to society. Lai et al. (2010) indicated that social customer value may be an antecedent to brand equity. Besides, Louro et al. (2001) stated that brand equity was created by an interaction between customers and a brand. 
Besides a competition on actual product offering, companies further offer augment customer value through augmented products with add-on features and services that distinguish it from similar product offerings. The augmented product makes a brand outperform its competitors because the augmented value delivered gives the consumer a reason to buy through a cultivation of the customer-brand relationship. Lee et al. (2018) found that the relationship has a major impact on CBE.

Previous research (e.g., Chang \& Weng, 2012; Long \& Schiffman, 2000; Shi \& Chow, 2016; Sweeney \& Soutar, 2001) asserted that functional consumer value, experiential consumer value, and social customer value had an impact on purchase-related attitude and/or behavior. All existing automobile manufacturers have offered these customer value through ranges of products, services, social contribution activities. However, the competition becomes much intense where some brands further shift from the delivery of conventional customer value (which includes functional, experiential, and social value) to augmented customer value in which customers are offered with various customer privilege programs.

CBE concerns a consumer's activities in relation to cognition, emotion, and behavior, and an individual's interactions with a product or service brand (Hollebeek et al., 2014). CBE has been a crucial element for a company in forging a relationship between its consumers (Dessart et al., 2016). Unlike most conventional concepts such as service quality or product satisfaction, CBE can predict brand loyalty more accurately because it can delve into the consumer-brand relationship (Hollebeek, 2011). Thus, CBE is indispensable to developing a strong brand (Hollebeek et al., 2014), and a firm can instill in its customers a sense of loyalty to its brand (Kandampully et al., 2015). However, only a few exploratory studies have investigated this relationship (e.g., Dwivedi, 2015; So et al., 2016).

$\mathrm{CBE}$ is a context-specific, situation-dependent psychological state characterized by cognition, emotion and conation (Brodie et al., 2011). It was noted that CBE took a major role in the process of an exchange between a brand and customers. Moreover, CBE reflects customer motive with different levels of intensity and valence (Brodie et al., 2011), because of a customer's interaction with the company's offering, a company, or a brand at the physical or emotional level (Hollebeek, 2011).

So et al. (2012) argued that CBE was determined by customer involvement, interactivity, customer rapport, brand trust, brand attachment, brand commitment, and brand performance while it influenced variables such as co-creation, customer satisfaction, brand experience, customer trust, brand commitment, brand loyalty, customer value, customer equity, brand reputation, brand recognition, and financial outcomes.

However, in contrast to So et al. (2012), Hollebeek and Chen (2014) conceptualized CBE as a process represented by a more inclusive conceptual framework, which depicted how CBE functioned. It was demonstrated that among the factors affecting CBE there were perceived brand and company actions, perceived brand quality and performance, perceived brand value, perceived brand innovativeness, delivery of brand promise, perceived brand, and company responsiveness. They argued that CBE contributed to attitude toward a brand and word-of-mouth dissemination.

Brand loyalty concerns a customer's strong determination to adhere to a particular brand over a long period of time and not being influenced by any factor that might result in brand switching (Oliver, 1999). It is not only the essence of brand equity (Keller, 2001), but also a leverage of competitiveness that helps a company establish an enduring tie with customers (Hwang \& Kandampully, 2012).

Factors such as perceived quality attributes, costs incurred by switching brands, and satisfaction with a brand are important to loyalty to a particular brand (Bowden, 2009; Kandampully et al., 2015). However, it was maintained that this viewpoint had a psychological perspective (DelgadoBallester \& Munuera-Alemán, 2005), and failed to view from a cognitive perspective that engaged decision making; neither was it considered from a sociological standpoint toward brand loyalty. Given that today's consumers take the role of a co-owner or co-creator of a brand (Gong, 2018), branding is oriented toward relationship building and maintaining (Delgado-Ballester \& MunueraAlemán, 2005). This focus promotes the customer-brand relationship in marketing these days. 
Brand loyalty has taken a new paradigm that incorporates novel constructs such as brand trust (Huang \& Guo, 2021), brand love (Albert et al., 2008), brand experience (Iglesias et al., 2019; Joshi \& Garg, 2021) and brand engagement (Hollebeek et al., 2014; McShane et al., 2021).

\section{AIMS AND HYPOTHESES}

This study is aimed at investigating the interplay of customer value, $\mathrm{CBE}$, and brand loyalty among the customers of medium-sized automobile brands in Thailand. Specifically, the study is aimed at ascertaining how well do customer value and CBE predict brand loyalty, and how much variance in brand value can be explained by scores on customer value and $\mathrm{CBE}$. The second purpose is to determine the degree to which functional, experiential, social, and augmented customer value affects CBE. Thirdly, the study assesses which customer value drives the current customers of the medium-sized automobile to engage with a brand.

Therefore, to address these objectives more clearly, the following hypotheses were formulated:

H1: Customer value has an impact on the degree to which automobile customers are loyal to their selected brand.

H2: Customer value has an impact on CBE.
H3: $\quad C B E$ has an impact on the degree to which automobile customers are loyal to their selected brand.

H4: CBE mediates the relationship of customer value to brand loyalty.

\section{DATA AND METHOD}

\subsection{Participants}

The study was targeted at the current owners of medium-sized passenger automobiles priced at over US\$32,900. In Thailand, this category of motor vehicles, commonly referred to as the $\mathrm{D}$ segment, is manufactured with four seats and primarily for use in the transportation of passengers. Among those offered in the market are Toyota Camry, Honda Accord, and Nissan Teana.

The sample was represented by the customers who at the time purchased a D-segment automobile. Multistage sampling method was applied in such a way that the sample of automobile customers was randomly drawn from a stratified random sample of dealerships around the country. The list of dealership customers was provided by the Automobile Dealership Association of Thailand.

Nunnally and Bernstein (1994) proposed the rule of 10 using covariance-based structural equa-

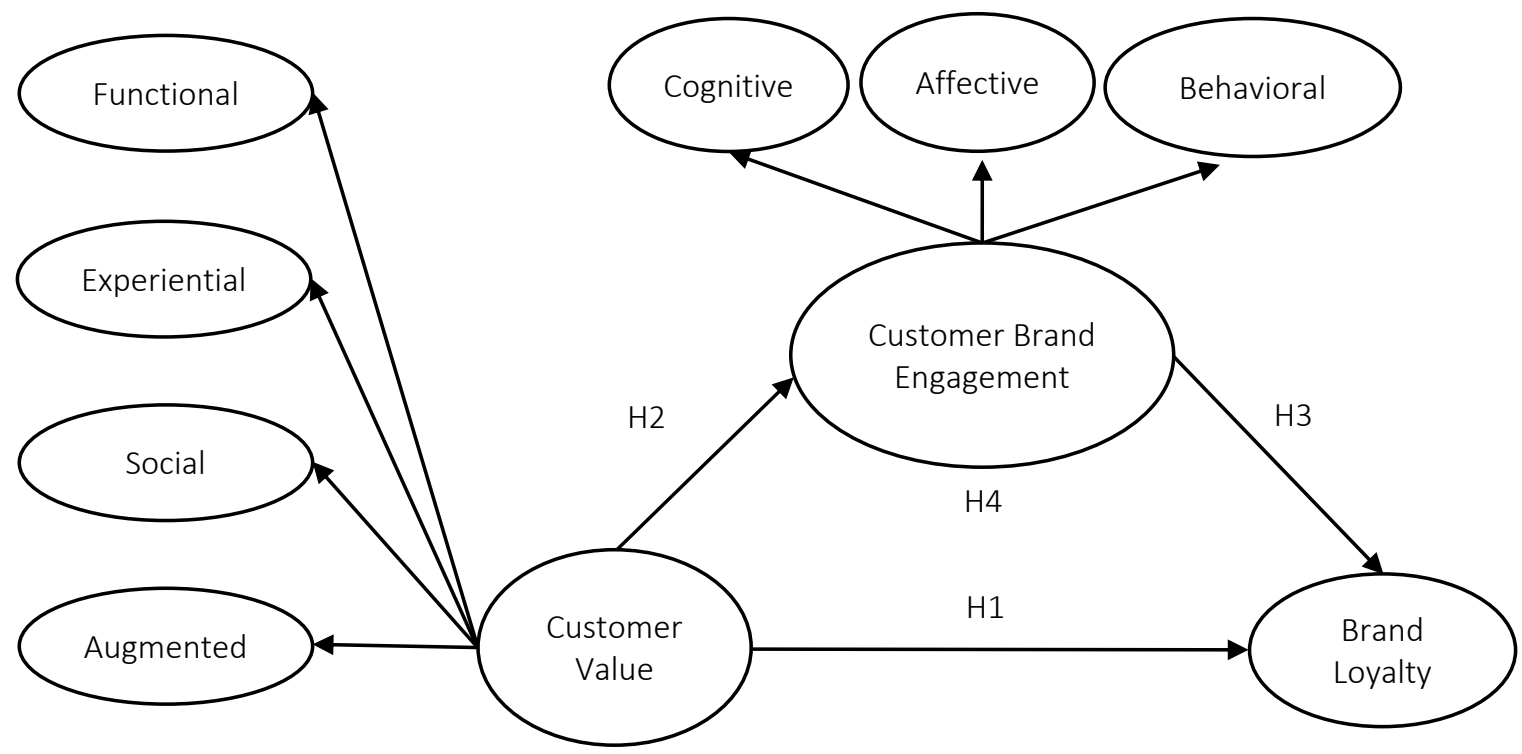

Figure 1. Conceptual framework 
tion modeling (SEM), which suggested that there should be 10 observations for each indicator in a model. The model in this study had 38 indicators so a minimum of 380 participants was needed to continue.

The respondents were grouped almost proportionately into three age groups: $25-39$ (33\%), 40-49 (33\%), and 50-59 (34\%). Most were single individuals $(68 \%)$ and had an average monthly income of US $\$ 2,000$ or more, and US\$3,290-10,000 for the household. Most of the respondents (46\%) favored Honda over the other makes.

\subsection{Measure}

All the scales used were developed on the basis of previous studies, extensive literature review and discussion with marketing professionals in the automobile business in Thailand. The content validity in relation to clarity, appropriateness and readability of the items was checked by seeking consultation with five experts in the field of automobile marketing. Furthermore, a panel of experts, namely a college student, a high school teacher and a marketing manager were asked to evaluate the readability of the scales. Five items were suggested to be reworded for clarification.

Eventually a pool of 38 items was selected for the initial item pool. The items were structured as a declarative sentence and in a Likert-type format. Then, the scales were administered to a pilot sample of customers from some dealerships. This step was recommended by Bradburn et al. (2007) to reduce content ambiguity before review by the content experts.

The questionnaire was translated into Thai by two Thai language specialists. Some discrepancies in terms of wording and sentence structure were detected between the two versions, thoroughly discussed and resolved until a new version was agreed upon. Thereafter, this version was back-translated into English by a bilingual scholar. Next, help was sought from a marketing academic who was a native speaker of English in comparing the back-translated version and the original version item by item along with the questionnaire instruction to assess their semantic equivalence. Some slight discrepancies were found and were re- solved by consultation among the individuals involved until they were considered equivalent.

Customer value had four dimensions. The functional, experiential, and social factors were each made up of five question items, while the augmented factor consisted of six question items. This set of 21 questions were developed based on DelgadoBallester and Sabiote (2005) and Wang and Lin (2010). CBE had three dimensions. The cognitive and behavior dimensions had four items for each, while the affective dimension had five items. This 13-item scale was adapted from Hollebeek et al. (2014) and Dwivedi (2015). Brand loyalty was a single-dimension scale with four question items. It was adapted from Yoo and Donthu (2001) and Dwivedi (2015).

The contents of each scale are displayed in Table 2. In responding to them, participants were required to identify their degree of agreement to each statement on a summated scale of 1 (= strongly disagree) to 5 (= strongly agree).

\subsection{Analysis}

SEM was executed to specify and evaluate both the measurement model represented by constructs and their indicators and the structural model depicting latent variables (Kline, 2015; Raykov \& Marcoulides, 2006), and, in this case, to test the relationship among customer value, CBE, and brand loyalty. An analysis of the hypothesized model was conducted employing IBM SPSS Amos 25 (Arbuckle, 2017).

\section{RESULTS}

Before starting the SEM analysis, zero-order correlations across each of the scaled measures were assessed. As portrayed in Table 1, the mean of the items was examined. Items were omitted if their means were extreme (over 5 or less than 1) or if the item-total correlation was below .2 or if their omission caused alpha to increase (Meir \& Gati, 1981). The Cronbach's alpha was calculated to gauge internal consistency reliability on all the measures in the proposed model. The results were significant and ranged from .70 (behavioral CBE) to .78 (affective CBE), confirming an adequate reliability 
level (Nunnally \& Bernstein, 1994; Schumacker \& Lomax, 2015).

Discriminant validity was proven to hold because the AVE of each of the latent constructs was higher than the highest squared correlation with any of the other latent variables (Fornell \& Larcker, 1981) (see Table 1). Moreover, the correlation between the constructs was within two standard errors (SE $=0.02, p<.001)$, confirming discriminant validity between the constructs (Anderson \& Gerbing, 1988). Moreover, no pairwise correlation exceeded .85 (Bagozzi \& Yi, 1988).

Not only were the average variances extracted well above .50 (Fornell \& Lacker, 1981; Hair et al., 2018), but the standardized factor loadings for each item of each construct were also greater than .5 , and the composite reliability values were greater than .70 (Hair et al., 2018). As such, these estimates provided evidence of convergent validity.

A chi-square test was performed to test whether the model whose correlation is fixed at one is different from that whose correlation is not fixed at one (Anderson \& Gerbing, 1988).

After examining the properties of the scales underlying the first-order model, factor analysis was conducted to evaluate the second-order model for customer value and CBE. The customer value construct had four dimensions. The overall index score has a standardized Cronbach's alpha of 80 . As shown in Table 2, the second-order standard- ized factor loadings were higher than .67 and significant $(p<.05)$.

The CBE construct had four dimensions. The most important dimension was the augmented customer value (.61), followed by functional (.56), social (.55), and experiential (.46) customer values. The fit indices confirmed the theoretical model fit the empirical data well, $\chi^{2}=79.65, p=.08$, CFI $=0.98$, TLI $=.97$, RMSEA $=.07$, SRMR $=.03$. The CBE construct had three dimensions. The behavioral component (.62) appeared as the most critical dimension, followed by the affective (.56) and cognitive (.45) components. As a whole, fit indices indicated the degree of robustness of the model, $\chi^{2}=$ $87.96, p=.06, \mathrm{CFI}=0.90, \mathrm{TLI}=.96, \mathrm{RMSEA}=.07$, $\mathrm{SRMR}=.04$.

To assess model fit for the structural model, the standards recommended by $\mathrm{Hu}$ and Bentler in 1999 (CFI $\geq .80$, AGFI $\geq .80$, and RMSEA $\leq .08$ ) were consulted and used as a benchmark. The results of the structural modeling analysis demonstrated the model provided acceptable fit to the data, $\chi^{2}=891.647, d f=116, p<.001$; CFI $=.89$; GFI $=.72 ; \mathrm{AGFI}=.70$; $\mathrm{RMSEA}=.08$.

In conclusion, according to the results from SEM, all the fit indices indicated that the model demonstrated goodness of fit to the data. The predictors were able to account for $35 \%$ of the variance in CBE. Experiential and augmented customer value influenced CBE; however, functional and social customer value did not influence CBE.

Table 1. Descriptive statistics, coefficient alphas, composite reliability, average variances extracted, and zero-order correlations

\begin{tabular}{|c|c|c|c|c|c|c|c|c|c|c|c|c|c|}
\hline Variable & $M$ & SD & $\alpha$ & CR & AVE & 1 & 2 & 3 & 4 & 5 & 6 & 7 & 8 \\
\hline FV & 4.47 & 0.30 & .75 & .61 & .72 & .85 & & & & & & & \\
\hline EV & 4.44 & 0.62 & .72 & .51 & .77 & .65 & .88 & & & & & & \\
\hline SV & 4.04 & 0.46 & .71 & .53 & .76 & .75 & .76 & .87 & & & & & \\
\hline AV & 3.83 & 0.80 & .78 & .58 & .70 & .77 & .67 & .81 & .84 & & & & \\
\hline $\mathrm{CC}$ & 4.02 & 1.02 & .77 & .64 & .79 & .65 & .65 & .66 & .65 & .89 & & & \\
\hline$A C$ & 3.11 & 0.80 & .75 & .63 & .68 & .75 & .72 & .75 & .73 & .69 & .82 & & \\
\hline$B C$ & 3.00 & 0.66 & .70 & .66 & .71 & .71 & .70 & .71 & .78 & .70 & .67 & .84 & \\
\hline $\mathrm{BL}$ & 3.95 & 0.89 & .74 & .68 & .72 & .61 & .62 & .63 & .65 & .72 & .75 & .66 & .85 \\
\hline
\end{tabular}

Note. All coefficients are significant at $p<.05$. Diagonals are the square root of AVE of each variable. FV $=$ functional consumer value; $\mathrm{EV}=$ experiential consumer value; $\mathrm{SV}=$ social consumer value; $\mathrm{AV}=$ augmented consumer value; $\mathrm{CC}=\operatorname{cognitive}$ customer brand engagement; $\mathrm{AC}=$ affective customer brand engagement; $\mathrm{BC}=$ behavioral customer brand engagement; $\mathrm{BL}=$ brand loyalty; $\alpha=$ internal consistency reliability; $C R=$ construct reliability; AVE = average variance extracted. 
Table 2. Factor loadings

Item

$\lambda$

Construct: Functional customer value (Delgado-Ballester \& Sabiote, 2015; Wang \& Lin, 2010)

\begin{tabular}{l} 
The automobile has high performance. \\
The automobile has a long life. \\
The automobile has a reasonable price. \\
The automobile comes with proper warranty. \\
The automobile has superior quality. \\
\hline \multicolumn{1}{c}{ Construct: Experiential customer value (Delgado-Ballester \& Sabiote, 2015; Wang \& Lin, 2010) } \\
\hline The brand understands what customers need. \\
The brand is familiar to me. \\
The brand's advertisement is true. \\
The brand is widely accepted and trusted. \\
The brand is modern and stylish.
\end{tabular}

Construct: Social customer value (Delgado-Ballester \& Sabiote, 2015; Wang \& Lin, 2010)

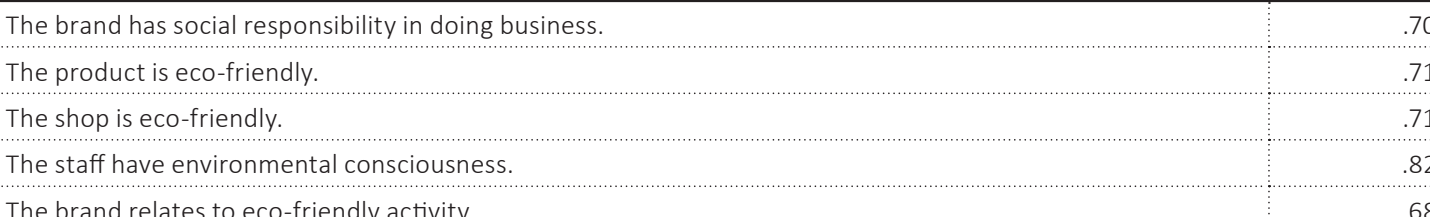

The brand relates to eco-friendly activity.

Construct: Augmented customer value (Delgado-Ballester \& Sabiote, 2015; Wang \& Lin, 2010)

The brand offers hotel and limousine to their customers.

The brand provides a free invitation to dining or workshop.

The brand provides a discount to current customers for buying a new car.

The brand provides a discount for maintenance and repairs.

The brand provides fast lane service to current customers for using after-sales service.

The brand provides customers gifts on special occasions like birthday.

The brand provides customers gifts on special occasions like birthday.
\begin{tabular}{l} 
Construct: Cognitive customer brand engagement (Hollebeek et al. 2014; Dwivedi, 2015) \\
\hline I contemplate about this brand.
\end{tabular}
This brand triggers my interest.
When I use this brand, I do not think of other brands.

Construct: Affective customer brand engagement (Hollebeek et al. 2014; Dwivedi, 2015)

\begin{tabular}{l} 
This brand makes me believe in my ability. \\
I feel proud upon using this brand. \\
\hline I am fond of this specific brand. \\
\hline Associating with this brand makes me happy. \\
\hline I feel enthusiastic about this brand.
\end{tabular}

Construct: Behavioral customer brand engagement (Hollebeek et al. 2014; Dwivedi, 2015)

It takes me time researching this brand.

I often choose this brand over the others in the product category.

Within the same product category, I always use this brand.

I have sufficient information about this brand.

Construct: Brand loyalty (Yoo \& Donthu, 2001; Dwivedi, 2015)

\begin{tabular}{l}
\hline I would recommend my friends to use this brand. \\
I will purchase this brand again in the future. \\
I will not buy a different brand if it is available in the store. \\
I am loyal to this brand.
\end{tabular}

Note. Factor loadings are significant. $\lambda=$ factor loading. 


\section{DISCUSSION}

The study complemented the existing body of knowledge on brand marketing by empirically validating some new concepts that have gained attention from academics and practitioners. Much has been discovered; however, there still are some unknowns, especially the interplay of $\mathrm{CBE}$, customer value and brand loyalty. Though extensively investigated, they are not sufficiently supported by robust evidence.

The study improved the comprehension of the mediating role CBE assumed on the impact of customer value on the degree to which automobile customers were loyal to their selected brand. CBE proved to be a good predictor of brand loyalty, so did customer value. CBE also mediated the relationship of customer value and brand loyalty in the automobile customer. Customer value had both direct and intervening effects on brand loyalty. Customers' tendency to repurchase an automobile from a particular manufacturer was a function of customer value.

The impact of consumer-brand relationships was substantiated by the results. These findings were not congruent with Rus (2016) who maintained that functional customer value could drive customer satisfaction but not brand loyalty. Besides, it was found to be consistent with Lee et al. (2018) who asserted that experiential customer value could affect to a large extent customer's brand choice for the future purchase.

Even though the results were contrary to Louro and Cunha (2001) and Lai et al. (2010), social customer value requires an extended interval coupled with accumulated interactive experience between brand and customers to form brand equity. Another observation was that the social contribution or social marketing activities used to deliver social customer value were company-centric, not customer-centric. As a result, the consumers felt less relevant to them.

This study confirmed Lee et al. (2018) who pointed out that augmented customer value can cultivate a customer-brand relationship. Consequently, the customer-brand relationship induces customers' desire to engage with a brand. It proved that augmented customer value, which included customer privilege programs, expedited services, and special discount for repurchase, could promote CBE and help sustain a long-term relationship with customers.

This study added to an emerging research topic and demonstrated the value of CBE. No prior study has examined the mediating effect of CBE across a va-

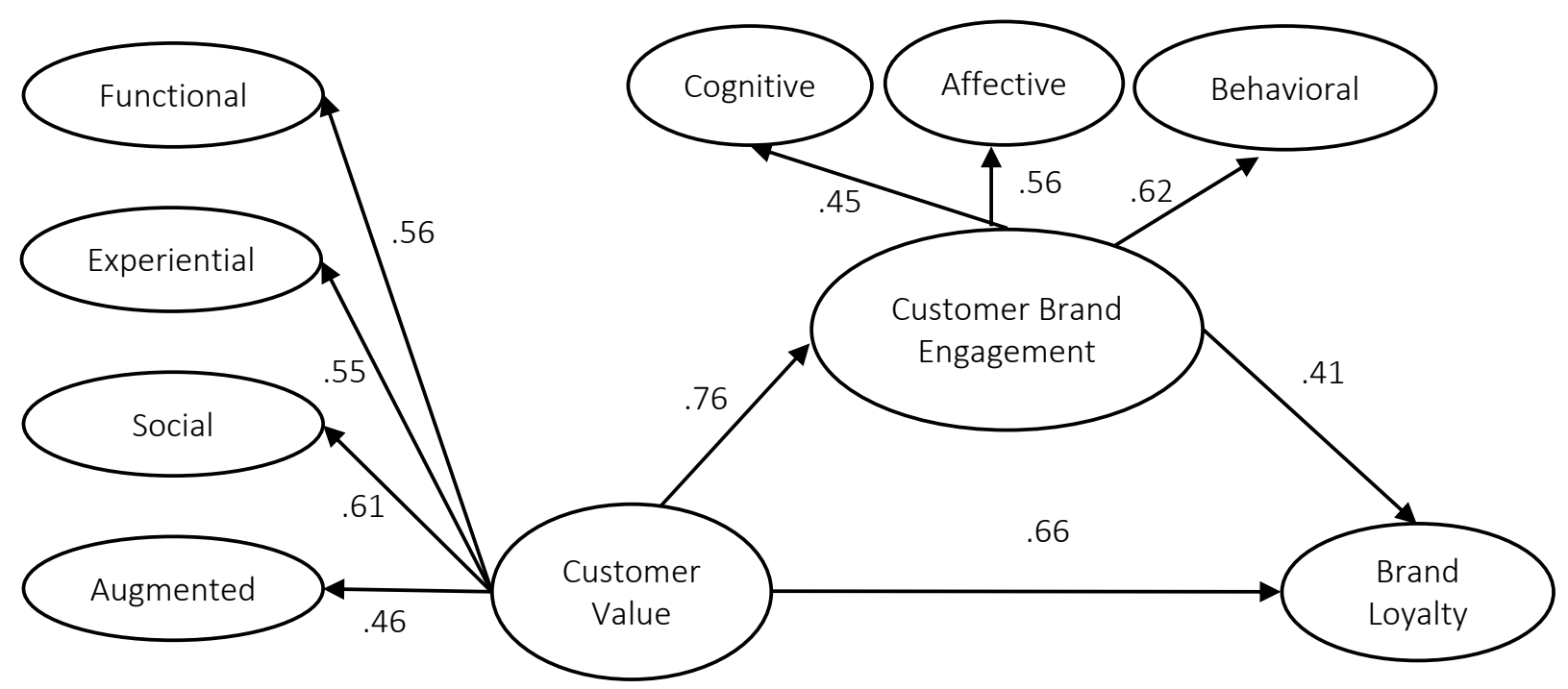

Note. This structural model predicts brand loyalty from customer value, with mediating effects of customer brand engagement. Statistics are standardized regression coefficients. All coefficients are significant at $p<.05$.

Figure 2. Structural model predicting brand loyalty 
riety of product offerings and product categories. Past research (e.g., Chang \& Weng, 2012; Long \& Schiffman, 2000; Shi \& Chow, 2016; Sweeney \& Soutar, 2001) provided a broad perspective of the relationship between functional, experiential, and social customer value and purchase-related attitude and/or behavior in the context of customer acquisition. However, this research extended the extant knowledge by providing a specific point of view about those customer value and specific construct or $\mathrm{CBE}$ in repurchasing automobiles.

This study suggests marketers maximize marketing efficiency to keep current customers loyal to the brand. Customer relationship can be established and maintained by utilizing both experiential and augmented consumer value. Specifically, marketers must heed customer needs and ensure that the company's brand is always on the top of their mind. Moreover, a brand must demonstrate to the customers that they are honest and genuine, as well as trustworthy. Besides, the look and feel of the brand must be always modern and stylish so that the customers want to relate to.

Since this study investigated the repurchase of the customers of automobiles, the findings may be generalizable to other product categories. Past research (e.g., Lee et al., 2018) did not directly investigate an antecedent such as augmented consumer value, but the consequence of the augmented customer value or relationship. Future research may attempt to examine other high-involvement products. However, those customer value may influence repurchase intention. It is suggested that future research will test the mediating role of $\mathrm{CBE}$, and repurchase intention as a dependent variable.

\section{CONCLUSION}

Automobile business is crucial to the Thai economy, as evidenced by prevalent production plants and sale operations that were established in the country several decades ago and still are thriving nowadays. Moreover, even though there are diverse modes of public transport in Thailand, domestic transport still largely depends on private automobile use. Additionally, they even manufacture and import automobile parts as a major source of gross domestic income.

This study demonstrated that customer value was a vital tool necessary for automobile businesses in maintaining a relationship with their customers. The study results strongly suggest that customer brand engagement, particularly, customer-oriented programs such as customer privilege recognition, fast track after-sale service for customers, and other similar customer relationship management techniques, had a measurable impact on brand loyalty. Significant differences were found in the increase of brand loyalty upon enhanced efforts on customer value.

Overall, the study contributes to extending the conventional marketing philosophy in that marketers must develop customer relationship programs to provide augmented benefits to meet or even exceed the expectations of their current customers.

\section{AUTHOR CONTRIBUTIONS}

Conceptualization: Pirayut Pattanayanon.

Data curation: Shixin Zhao, Sid Terason.

Formal analysis: Pirayut Pattanayanon, Shixin Zhao, Sid Terason.

Funding acquisition: Shixin Zhao.

Investigation: Pirayut Pattanayanon.

Methodology: Pirayut Pattanayanon, Sid Terason.

Project administration: Sid Terason.

Resources: Pirayut Pattanayanon, Shixin Zhao, Sid Terason.

Software: Sid Terason. 
Supervision: Pirayut Pattanayanon.

Validation: Pirayut Pattanayanon, Sid Terason.

Visualization: Sid Terason, Shixin Zhao.

Writing - original draft: Pirayut Pattanayanon.

Writing - review \& editing: Sid Terason.

\section{REFERENCES}

1. Albert, N., Merunka, D., \& Valette-Florence, P. (2008). When consumers love their brands: Exploring the concept and its dimensions. Journal of Business Research, 61(10), 10621075. https://doi.org/10.1016/j. jbusres.2007.09.014

2. Anderson, J. C., \& Gerbing, D. W. (1988). Structural equation modeling in practice: A review and recommended two-step approach. Psychological Bulletin, 103(3), 411-423. https://doi. org/10.1037/0033-2909.103.3.411

3. Arbuckle, J. L. (2017). IBM SPSS Amos 25 user's guide. Amos Development Corporation.

4. Babin, B. J., Darden, W. R., \& Griffin, M. (1994). Work and/ or fun: Measuring hedonic and utilitarian shopping value. Journal of Consumer Research, 20, 644-656. https://doi.org/10.1086/209376

5. Bagozzi, R., \& Yi, Y. (1988). On the evaluation of structural equation models. Journal of the Academy of Marketing Science, 16(1), 74-94. https://doi. org/10.1007/BF02723327

6. Ballester, E., Espallardo, M., \& Orejuela, A. (2014). Store image influences in consumers' perceptions of store brands: The moderating role of value consciousness. European Journal of Marketing, 48, 1850-1869. https://doi.org/10.1108/EJM-022012-0087

7. Bowden, J. (2009). The process of customer engagement: A conceptual framework. Journal of Marketing Theory and Practice, 17(1), 63-74. https:// doi.org/10.2753/MTP10696679170105

8. Bradburn, N. M., Sudman, S., \& Wansink, B. (2007). Asking questions: The definitive guide to questionnaire design - For market research, political polls, and social and health questionnaires (2nd ed.). Jossey-Bass.

9. Brodie, R. J., Hollebeek, L. D., Juric, B., \& Ilic, A. (2011). Customer engagement: Conceptual domain, fundamental propositions, and implications for research. Journal of Service Research, 14(3), 252-271. https://doi. org/10.1177/1094670511411703

10. Chang, W. L., \& Weng, S. S. (2012). Revisiting customer value by forecasting e-service usage. Journal of Computer Information Systems, 52(3), 41-49. Retrieved from https://www.tandfonline. com/doi/abs/10.1080/08874417.20 12.11645557

11. Delgado-Ballester, E., \& Sabiote, E. F. (2015). Brand experimental value versus brand functional value: Which matters more for the brand? European Journal of Marketing, 49(11/12), 1857-1879. https://doi.org/10.1108/EJM-022014-0129

12. Delgado-Ballester, E., \&MunueraAlemán, L. (2005). Does brand trust matter to brand equity. Journal of Product \& Brand Management, 14(3), 187-196. https://doi.org/10.1016/j.sbspro.2012.09.1120

13. Dessart, L., Veloutsou, C., \& Morgan-Thomas, A. (2016). Capturing consumer engagement: Duality, dimensionality and measurement. Journal of Marketing Management, 32(5-6), 399-426. https://doi.org/10.1080/0 267257X.2015.1130738

14. Dwivedi, A. (2015). A higherorder model of consumer brand engagement and its impact on loyalty intentions. Journal of Retailing and Consumer
Services, 24, 100-109. https:// doi.org/10.1016/j.jretconser.2015.02.007

15. Fernandes, T., \& Moreira, M. (2019). Consumer brand engagement, satisfaction and brand loyalty: A comparative study between functional and emotional brand relationships. Journal of Product \& Brand Management, 28(2), 274-286. https://doi.org/10.1108/JPBM-082017-1545

16. Hair, J. F., Babin, B. J., Black, W. C., \& Anderson, R. E. (2018). Multivariate data analysis (8th ed.). Pearson.

17. Hapsari, R., \& Dean, M. C. (2016). The mediating role of perceived value on the relationship between service quality and customer satisfaction: Evidence from Indonesian airline passengers. Procedia Economics and Finance, 35, 388-395. https://doi.org/10.1016/S22125671(16)00048-4

18. Hollebeek, L. D. (2011). Exploring customer brand engagement: Definition and themes. Journal of Strategic Marketing, 19(7), 555573. https://doi.org/10.1080/09652 54X.2011.599493

19. Hollebeek, L. D., \& Chen, T. (2014). Exploring positivelyversus negatively-valenced brand engagement: A conceptual model. Journal of Product \& Brand Management, 23(1), 62-74. https:// doi.org/10.1108/JPBM-06-20130332

20. Hollebeek, L. D., Glynn, M. S., \& Brodie, R. J. (2014). Consumer brand engagement in social media: Conceptualization, scale development and validation. Journal of Interactive Marketing, 28(2), 149-165. https://doi. org/10.1016/j.intmar.2013.12.002 
21. Hollebeek, L. D., Juric, B., \& Tang, W. (2017). Virtual brand community engagement practices: A refined typology and model. Journal of Services Marketing, 31(3), 204-217. https://doi. org/10.1108/JSM-01-2016-0006

22. Hu, L., \& Bentler, P. M. (1999). Cutoff criteria for fit indices in covariance structure analysis: Conventional criteria versus new alternatives. Structural Equation Modeling: A Multidisciplinary Journal, 6(1), 1-55. https://doi. org/10.1080/10705519909540118

23. Huang, C., \& Guo, R. (2021). The effect of a green brand story on perceived brand authenticity and brand trust: the role of narrative rhetoric. Journal of Brand Management, 28, 60-76. https:// doi.org/10.1057/s41262-02000213-7

24. Hwang, J., \& Kandampully, J. (2012). The role of emotional aspects in younger consumerbrand relationship. Journal of Product \& Brand Management, 21(2), 98-108. https://doi. org/10.1108/10610421211215517

25. Iglesias, O., Markovicb, S., \& Rialp, J. (2019). How does sensory brand experience influence brand equity? Considering the roles of customer satisfaction, customer affective commitment, and employee empathy. Journal of Business Research, 96, 343354. https://doi.org/10.1016/j. jbusres.2018.05.043

26. Joshi, R., \& Garg, P. (2021). Role of brand experience in shaping brand love. International Journal of Consumer Studies, 45(2), 259272. https://doi.org/10.1111/ ijcs. 12618

27. Kandampully, J., Zhang, T., \& Bilgihan, A. (2015). Customer loyalty: A review and future directions with a special focus on the hospitality industry. International Journal of Contemporary Hospitality Management, 27(3), 379414. https://doi.org/10.1108/ IJCHM-03-2014-0151

28. Keller, L. K. (2001). Building customer-based brand equity: A blueprint for creating strong brands.
Marketing Science Institute.

29. Kline, R. B. (2015). Principles and practice of structural equation modeling (4th ed.). The Guilford Press.

30. Lai, C. S., Chiu, C. J., Yang, C. F., \& Pai, D. C. (2010). The effects of corporate social responsibility on brand performance: The mediating effect of industrial brand equity and corporate reputation. Journal of Business Ethics, 95, 457-469. https://doi. org/10.1007/s10551-010-0433-1

31. Lee, S. H., Lee, J. E., \& Kim, H. W. (2018). A customer value theory approach to the engagement with a brand: The case of Kakao Talk Plus in Korea. Asia Pacific Journal of Information Systems, 28(1), 36-60. https://doi.org/10.14329/ apjis.2018.28.1.36

32. Long, M. M., \& Schiffman, L. G. (2000). Consumption values and relationships: Segmenting the market for frequency programs. Journal of Consumer Marketing, 17(3), 214-232. https://doi. org/10.1108/07363760010329201

33. Louro, M. J., \& Cunha, P. V. (2001). Brand Management Paradigms. Journal of Marketing Management, 17, 849-875. https://doi. org/10.1362/026725701323366845

34. Lusch, R., \& Vargo, S. (2014). Service-dominant logic: Premises, perspectives, possibilities. Cambridge University Press.

35. Maikaew, P. (2019, November 3). Automotive industry at a turning point. Bangkok Post. Retrieved from https://www.bangkokpost. com/business/1606570/automotive-industry-at-a-turning-point

36. McShane, L., Pancer, E., Poole, M., \& Deng, Q. (2021). Emoji, playfulness, and brand engagement on twitter. Journal of Interactive Marketing, 53, 96-110. https://doi.org/10.1016/j.intmar.2020.06.002

37. Meir, E. I., \& Gati, I. (1981) Guidelines for item selection in inventories yielding score profiles. Educational and Psychological Measurement, 41(4), 1011-1016. https://doi. org/10.1177/001316448104100409
38. Nunnally, J. C., \& Bernstein, I. H. (1994). The assessment of reliability. Psychometric Theory, 3, 248-292.

39. Petrick, J. F. (2002). Experience use history as segmentation tool to examine golf travellers satisfaction, perceived value and repurchase intentions. Journal of Vacation Marketing, 8(4), 332-342. https://doi. org/10.1177/135676670200800404

40. Raykov, T., \& Marcoulides, G. A. (2006). A first course in structural equation modeling ( $2 \mathrm{nd}$ ed.). Lawrence Erlbaum.

41. Rus, M. I. (2016, October 21-22). Perceived value among ClujNapoca automobile owners. 9th International Conference Marketing from Information to Decision. Cluj-Napoca, Romania. https://econ.ubbcluj.ro/mid/journal/abstracting.php

42. Schumacker, R. E., \& Lomax, R. G. (2015). A beginner's guide to structural equation modeling (4th ed.). Routledge.

43. Shi, S., Chen, Y., \& Chow, S. W. (2016). Key values driving continued interaction on brand pages in social media: An examination across genders. Computers in Human Behaviour, 62, 578-589. https://doi. org/10.1016/j.chb.2016.04.017

44. So, K. K. F., King, C., \& Sparks, B. (2012). Customer engagement with tourism brands: Scale development and validation. Journal of Hospitality \& Tourism Research, 38(3), 304-329. https://doi. org/10.1177/1096348012451456

45. Sweeney, J. C., \& Soutar, G. N. (2001). Consumer perceived value: The development of a multiple item scale. Journal of Retailing, 77(2), 203-220. https://doi.org/10.1016/S00224359(01)00041-0

46. Tabachnick, B., \& Fidell, L. (2019). Using multivariate statistics (7th ed.). Pearson.

47. Verma, V., Sharma, D., \& Sheth, J. (2016). Does relationship marketing matter in online retailing? A meta-analytic 
approach. Journal of the Academy of Marketing Science, 44(2), 206-

217. https://doi.org/10.1007/ s11747-015-0429-6

48. Wang, C. Y., \& Lin, L. H.

(2010). A study of the effect of TV drama on relationships among tourists' experiential marketing, experiential value and satisfaction. International Journal of Organisation Innovation, 2(3), 107-123. Retrieved from https://wenku.baidu.com/view/ f9c11f778e9951e79b8927b6.html

49. Woodruff, R. B. (1997). Customer value: The next source of competitive advantage. Journal of the Academy of Marketing
Science, 25, 139-153. https://doi. org/10.1007/BF02894350

50. Yoo, B., \& Donthu, N. (2001). Developing and validating a multidimensional consumerbased brand equity scale. Journal of Business Research, 52(1), 1-14. https://doi.org/10.1016/S01482963(99)00098-3 